\section{PROJECT STAFF}

Another article in this newsletter outlines the responsibilities of the five editors of the Project. Thanks to the award of the grant they have been joined by a large support staff helping out in all areas of the Project. Ways to make the most efficient use of the new people has involved the editors in much rethinking of their editorial principles and agendas and has caused some humorous trial and error proceedings. A Project office has been established on the seventh floor of Togo Salmon Hall, about a five-minute walk from the Russell Archives. What follows is a brief introduction to our staff.

Diane M. Kerss, as the readers of Russell know, worked in the Russell Archives for the past ten years. She has assumed the important job of Administrative Coordinator of the Typographical Production Unit. Her two staff members are Carmen Stermann and Jackie Hassan. Carmen, who is the Project's graphic artist and apprentice photocompositor, is a recent graduate in graphic design from Sheridan College in Oakville. Jackie, our part-time photo compositor, came to us from a company in Toronto. Since February, Myrna-Gail McDonald has been working as a part-time clerktypist. She types textual notes and annotations which, after revisions, are typeset by the Production Unit.

Three Research Assistants have been hired-Dr. Gregory Moore, Dr. Margaret Moran and Paul Gallina, M.A., M.L.s. Gregory joined the Project in September as the resident historian of mathematics. Working both here and at the University of Toronto, where he teaches in the Department of Mathematics, he has helped to supply annotations, textual notes and translations (from French to English) of Russell's mathematical articles. Margaret, whose thesis defence in English Literature took place in November at the University of Toronto, has been working since September on verifying the annotations for Volume 1 , as well as supplying new annotations for that volume and Volume 12. In addition she has worked on collations and textual notes while reading widely on topics central to Russell. Paul, who has been with the Project since mid-August, is the Bibliographical Assistant to the Textual Editor. Researching formats and citations, drafting the Bibliographical Index for Volume 1 and searching for missing Russell material are only three of many tasks he has performed so far. The editors have also had help in accumulating and checking annotations and headnote information from Catherine Funnell, who has an M.A. in History and an M.L.S. She has been with us on a part-time basis since January. In addition, Sheila Turcon, M.A., Research Assistant and Secretary, has been charged with the demanding tasks of drafting a general index and a chronology for Volume 1 and, we presume, subsequent volumes.

A number of graduate students assisted the editors with their research during the academic year, working ten hours each per week. Richard Sams and Marilyn Mason worked with Richard Rempel on Volume 1. Richard had read the correspondence of several people looking for references to go into the headnotes before he left McMaster in December, while Marilyn assisted with annotations and searched for quotations. She is currently working on Volume 12. James Dianda and John King worked with Nicholas Griffin on Volumes 1 and 2. James has checked references and researched Kantianism in Britain during the period 1840-90, while John has searched for biographical data and done many proofreadings and a difficult collation. And since January, B.P. Frohmann and W. G. Stratton have worked for John Slater at the University of Toronto.

During the summer of 1980 four undergraduate students were hired full-time. Hilary Turner searched for information for use in headnotes and annotations mainly for Volume 12 . She also coordinated the work of the other students-Don Ross, who for the second summer did annotation research for Volumes 1 and 13; Ben Zipursky, who assisted with Volume 2 and other philosophical papers; and Allan Siaroff, who helped with the research for headnotes to Volume 13. This summer, work has just begun for the four students hired. Ben has been joined by three new students-Maria Forte, Daphne Jarvis and James O'Meara. All students so far employed have been a great help to the editors.

Assisting all the researchers and students has been Dr. Carl Spadoni. Carl was named Assistant Archivist in July, freeing Ken Blackwell to spend half his time on the Project. As part of Carl's many archival duties-including work on the index to the Archives II Catalogue and training the new archival assistant, Cheryl Walker-he has been assisting members of the Project with their research by pointing out associations of persons and documents from his knowledge of Russell gained during his own dissertation research and the cataloguing of Archives II.

This then is the team which has been assembled. There are encouraging signs that we will form as cohesive a group as the five editors and Diane did; if this proves to be the case, the Project will be that much richer. In future editions of this newsletter, you will come to know us better, as many of the members just introduced to you contribute their thoughts and ideas on their work.-S. T. 